\title{
PALEOMAGNETIC CONSTRAINTS ON THE ASSEMBLY OF THE OLD RED CONTINENT
}

\author{
ROB VAN DER VOO
}

Department of Geological Sciences, University of Michigan, Ann Arbor, MI. 48109 (U.S.A.)

(Accepted May 27, 1982)

\begin{abstract}
Van der Voo, R., 1983. Paleomagnetic constraints on the assembly of the Old Red Continent.

Tectonophysics, 91: 271-283.

A model is proposed on the basis of paleomagnetic and geological arguments for the assembly of the Old Red Continent, which in the Devonian comprised North America, the Baltic Shield and Russian platform, as well as a third element called "Armorica". The latter is thought to have included most of Hercynian Europe and southern England and Wales, as well as possibly the Avalonian terranes of northeastern North America and perhaps some parts of the Atlas ranges and Moroccan Meseta. The model envisions a Late Ordovician (Taconic) collision of North America and Armorica, which are joined in the Late Silurian by the Baltic Shield and Russian platform. Not until the late Early Carboniferous did Gondwana join the Old Red Continent in a collision responsible for a large internal megashear parallel to the Caledonian orogenic belt as well as the Hercynian-Alleghenian orogeny. Subduction of the large Siluro-Devonian ocean between Gondwana and the Old Red Continent is held responsible for the mid-Devonian Acadian orogeny.
\end{abstract}

\section{INTRODUCTION}

For the better part of this century a Devonian paleogeographic element has been known as the "Old Red Continent", so called because of the occurrence of a typical post-Caledonian continental molasse facies, the Old Red Sandstone. This facies occurs on the Baltic Shield, large parts of the Russian platform, in the Ardennes and Great Britain, as well as in Greenland and northeastern North America as far south as the Catskill delta in the Central Appalachians. In addition, perhaps questionable occurrences, such as in Normandy (France) should be mentioned.

Reliable paleomagnetic data for most of these areas have become available, gencrally in the last decade, and they confirm that these elements formed a coherent landmass; in this paper I will denote this landmass as the Old Red Continent (ORC).

Figure 1 shows a paleogeographic map for Middle to Late Devonian times on the 
basis of these paleomagnetic data. It appears that Gondwana was at this time still separated from the ORC by a wide ocean; not until late Early Carboniferous time did Gondwana collide with the ORC to produce the Hercynian-Alleghenian orogeny (Lefort and Van der Voo. 1981; Van der Voo, 1982). For this reason, the

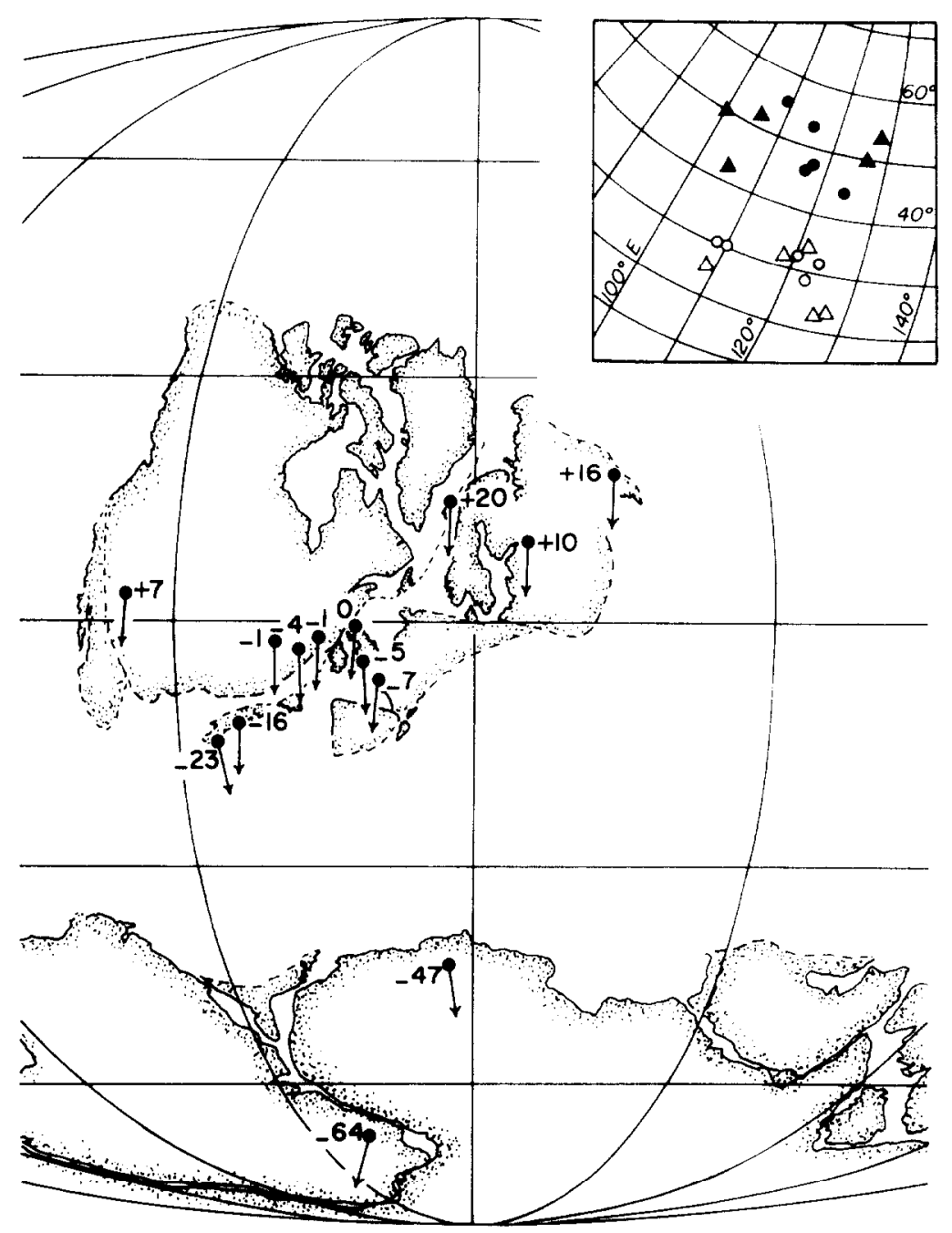

Fig. 1. Paleogeographic map for Middle to Late Devonian time (from Van der Voo and Scotese, 1981). Paleomagnetic results have been used to position the continental blocks and are shown with their declinations (as arrows) and paleolatitude values. The inset shows the paleopoles on which this reconstruction is based, with the North American craton (filled circles) and Acadian displaced terrane (open triangles) in their present-day position, and Europe (open circles) and northernmost Scotland (filled triangles) rotated against North America in the reconstruction of Bullard et al. (1965). The difference between the American and European poles in the Bullard reconstruction is statistically significant and mandates the fit of the paleogeographic map shown here. 
position of Gondwana or of any other presumably isolated landmass (Siberia, China, possible microplates) does not enter into the discussion of this paper.

The configuration of the ORC is different from that of the generally accepted continental reconstructions for Permian and Mesozoic time (e.g., Bullard et al., 1965). The difference can readily be seen in Fig. 1 by comparing the positions of the west coast of Norway and the northeast coast of Greenland, which in the usual Permian fits are directly juxtaposed. As argued by Scotese et al. (1979) and Van der Voo and Scotese (1981), the paleomagnetic data for the Devonian, Carboniferous and Permian suggest that a sinistral megashear along faults within and parallel to the Caledonian chains occurred during the Carboniferous. I will return to this megashear in a later section.

Of more central interest to this paper is the question how the tectonic elements of the ORC assembled in pre-Late Devonian times. Two of these elements are characterized by an internal coherence and lack of any Paleozoic fold belts other than those at their margins: the combined Baltic Shield-Russian platform ("Baltica") and the North American craton, including Greenland in its pre-drift position ("Laurentia"). The third element has been proposed on the basis of paleomagnetic data and on a great similarity in Late Precambrian and early Paleozoic geologic histories, but has been internally deformed during the middle and late Paleozoic orogenies: this element has been called "Armorica" (Van der Voo, 1979, 1982; Hagstrum et al., 1980) on the basis of the central position and available paleomagnetic data of the Armorican Massif (France). Armorica is thought to have comprised almost all of Hercynian Europe with its Precambrian nuclei, southern England and Wales, possibly the coastal Avalon terranes of northeastern North America and perhaps some elements in the Atlas ranges of Morocco.

Before turning to the pre-Late Devonian history, it is important to stress that all three elements, Laurentia, Baltica and Armorica, were already assembled by midDevonian time. Evidence for this can, in the case of the Baltica-Laurentia pair, be seen in the absence of any decper-water marine sedimentation younger than Late Silurian, which argues for a continuity of continental conditions between them. The evidence for Armorica is based on the Late Devonian and Early Carboniferous paleomagnetic data from France (Jones et al., 1979) and from the Avalon terranes (Robertson et al., 1968; Kent and Opdyke, 1978, inter alias). More recent information from northern Spain (Perroud and Bonhommet, 1981) and Hercynian Germany (Bachtadse et al., 1981) has confirmed this. If any deep-water basins existed in Late Devonian to Early Carboniferous times between Armorica and Laurentia or Baltica, such as perhaps the Kulm basins in Great Britain and Germany (Johnson, 1973, 1974), they must have been relatively minor in latitudinal width as argued by Jones et al. (1979).

In the following section, I will discuss how the locations of the early to middle Paleozoic orogenic belts between Baltica and Laurentia and in and around Armorica, can be used to constrain the models for the assembly of the ORC to a few logical 
alternatives. This then is followed by an analysis of the available paleomagnetic data, which-although not totally definitive-seems to enable us to state a preference for one of the models.

\section{MODELS FOR THE ASSEMBLY OF THE OLD RED CONTINENT}

It follows from the preceding discussion that the Early Devonian, Silurian and Ordovician are the periods in which most of the assembly action must have taken place. Until recently there were few or no paleomagnetic data for these periods, and even now the paleopoles for Baltica and Hercynian Europe (as part of Armorica) are too few to develop geotectonic models for the assembly of the ORC. The premise of the models is, of course, that Laurentia, Baltica and Armorica were indeed dispersed. i.e. not together, earlier in the Paleozoic. Evidence for this can be found in Cambrian and Cambro-Ordovician paleomagnetism and faunal provincialities (e.g.. Scotese et al., 1979), and few scientists question this premise.

Because of the paucity of Ordovician and Silurian paleopoles, it seems more fruitful to set up geotectonic models for the assembly on the basis of geological information, and then to test these models with the available paleopoles. If the ORC was assembled by the closing of oceans in a plate-tectonic framework, the resulting continent-continent collisions should be marked by orogenic belts. Nevertheless, it is worth keeping in mind that the reverse is not necessarily true, since orogenies may be produced by subduction without collisions or by collisions between continents and island arcs or microplates.

In the ORC, the orogenies during the time of interest comprise the Taconic, Caledonian and Acadian events, each in the strictest (and local) sense of the words. The location and timing of these orogenies, when interpreted in terms of possible continent-continent collisions, is less complex than at first might be suspected. The Caledonian orogeny, traditionally assumed to have its climax at the Silurian-Devonian boundary, occurs at the western and southern margins of Baltica and constitutes the final paroxism of an early to middle Paleozoic sequence of orogenic phases. Its well-known surface expressions in western Scandinavia trend into the North Sea and Great Britain, from where a less well-known branch trends east to southeast through the subsurface of the low countries, northern Germany, and into Poland (Ziegler, 1978; Zwart and Dornsiepen, 1978). Outcrops in the Ardennes and in the Holy Cross mountains in Poland are incorporated in the latter zone. Outside Baltica and Great Britain, the Caledonides have, of course, their counterpart in Greenland. Well inside in what we have called Armorica, many references can be found to "Caledonian" phases, but this European use of the term is mostly incorrect, as it often includes events dated as Ordovician with radiometric ages older than approximately $435 \mathrm{Ma}$. Many authors have argued, consequently, that the Caledonian sensu stricto does not occur inside Hercynian Europe (e.g., Schwan, 1962; Bradshaw et al., 1967; Heinisch and Schmidt, 1976; Chaloupsky, 1978). It also does not occur 


\section{A. Early Silurian}

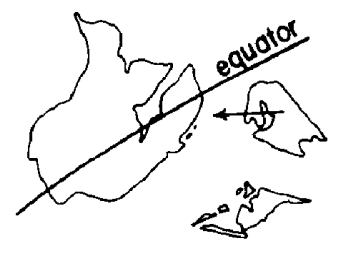

D.Middle Ordovician

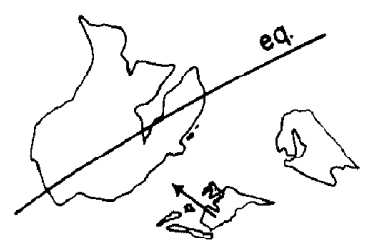

B.Early Devonian

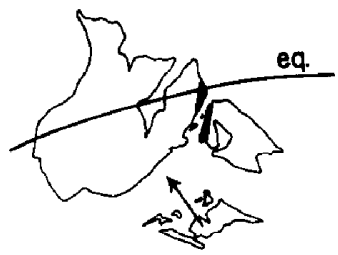

E. Early Silurion

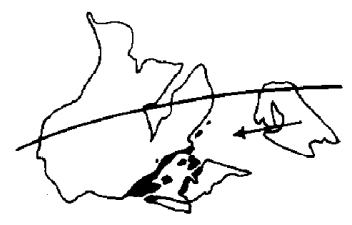

C. Lote Devonian

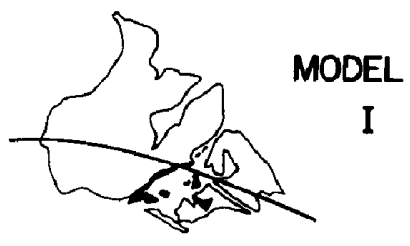

F. Late Devonian

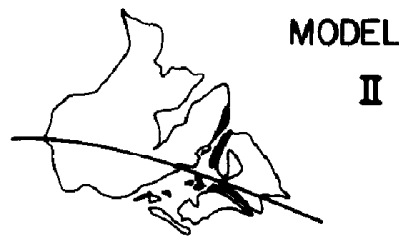

Fig. 2. Schematic models for the assembly of the Old Red Continent. A, B and C show model I (Kent, 1980) and D, E and F show model II (Van der Voo, 1979, 1982). The areas in black represent mountain belts formed in the period preceding the one shown by continent-continent collision (B: Caledonian; $\mathrm{C}$. Acadian; E: Taconic; F: Caledonian). The arrows indicate the generalized approach of the continental elements Baltica and Armorica with respect to Laurentia.

in the North American Appalachians between Newfoundland and Alabama.

The Acadian orogeny, on the other hand, if taken to be distinct from the Caledonian since it peaked at late Early to Middle Devonian time, does not occur in Baltica. It is found principally in the North American Appalachians and in the southern zones of the Hercynian belts in France. In Great Britain, Early Devonian phases can be demonstrated, but apparently they have not been major.

The Taconic orogeny, finally, parallels or coincides with the Acadian in the Appalachians and has perhaps equivalents in Wales with its Ordovician volcanism and plutonism, western France (Lefort, 1977) and western Spain and Portugal (e.g., Priem et al., 1966). Other occurrences in Sardinia (Sardic phase of Stille, 1924; see also Vardabasso, 1963), Germany and the Hercynian basement of the Alps (e.g., Schönenberg, 1967; Förster and Leonhardt, 1972; Flügel, 1975; Heinisch and Schmidt, 1976) testify to the tectonic unrest during the Ordovician in Armorica.

Considering now the coalescence of Laurentia, Baltica and Armorica, with the goal of ending up in the ORC configuration of Fig. 1, it is best to proceed in pairs. The clearest picture is provided by the Laurentia-Baltica pair, where at their joint boundary only the Caledonian orogeny is found. This provides the first step in the models: by the Late Silurian-Earliest Devonian, Baltica and Laurentia had collided. The choice is then: did Armorica join the Baltica-Laurentia pair after the Caledonian orogeny, by necessity producing the Acadian orogeny as proposed by Kent (1980), or had Armorica already joined Laurentia during the Ordovician, producing the Taconic deformations? The two models are schematically illustrated in Fig. 2. Van 
der Voo $(1979,1982)$ favored the second model on the basis of the fact that both of Baltica's margins inside the ORC are only marked by Caledonian orogenic belts. which suggests that it collided with the combined Laurentia-Armorica landmass.

In the model of Kent (Fig. 2A-C). the Taconic orogeny is left unexplained, i.e., perhaps ascribed to a (minor?) collision with an island arc or to subduction without collision. In the model of Van der Voo (Fig. 2D-F), the Acadian orogeny is left unexplained, and perhaps better referred to as an Andean-type orogeny (without continent-continent collision) occurring at the southern margin (see Fig. 1) of the ORC when subduction of the ocean between the ORC and Gondwana accelerated during the Devonian.

A choice between these models is quite difficult on the basis of geological information alone, in the absence of any quantifying data. Detailed and reliable paleomagnetic information could settle the question, but the data at present are sparse enough to leave some ambiguity. This paper is intended, therefore, to propose the models as working hypotheses to be tested with future work, which hopefully will be stimulated by the following analysis of the presently available paleopoles.

\section{PALEOMAGNETIC ANALYSIS}

Ordovician and Silurian paleopoles for North America and Europe have been compared in order to test the models of their assembly and relative positions at these times. The data for Europe outside Baltica come mostly from Great Britain with a few paleopoles available from Hercynian Europe, as shown in Fig. 3. Implicit in my

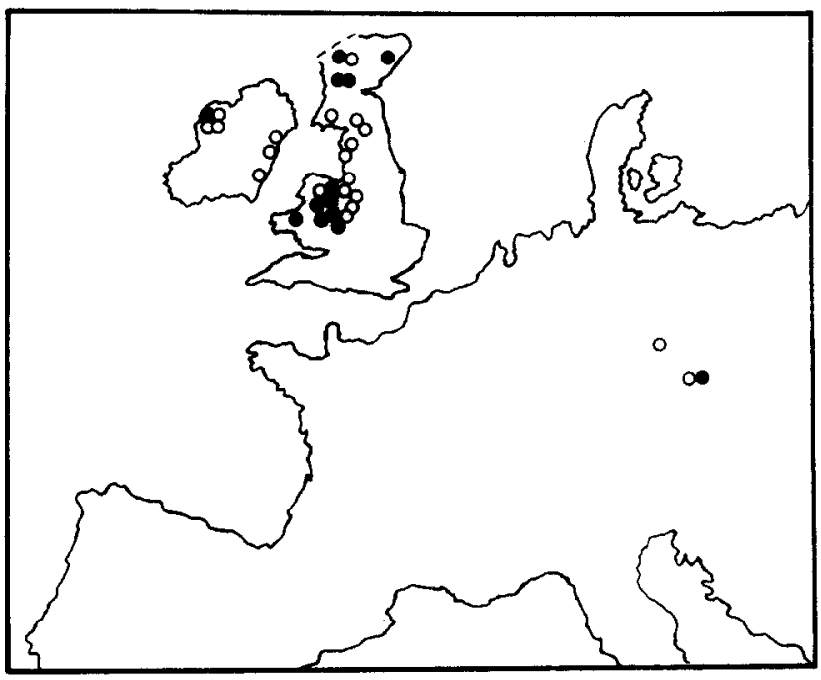

Fig. 3. Map of Western Europe outside Baltica, with the Ordovician (open symbols) and Silurian (filled symbols) paleomagnetic localities of Table 1 . 
analysis is the notion that these European areas outside Baltica comprise a single (Armorica) plate, and that a comparison of the American and European paleopoles is indeed a comparison between Laurentia and Armorica.

Since Armorica, however, was internally deformed during the later Paleozoic orogenies, one has to allow for possible local rotations of blocks or thrustsheets, which may have disturbed the original coherence of the paleomagnetic declinations. The inclinations, on the other hand, should be reliable paleolatitude indicators in the case of stratified rocks.

Morris (1976) was the first to recognize that Ordovician and Silurian data from Great Britain and the U.S.A. indicated similar latitudinal positions for the two. Piper (1979) updated the analysis and suggested some relative in-situ rotations for the British Isles. Here the analysis is extended in order to determine the relative paleolatitudes for the entire time between Early Ordovician and Late Carboniferous. It can be concluded on the basis of the comparison (Table I; Fig. 4) that Armorica and Laurentia maintained a near-constant relative paleolatitude position from Ordovician through Early Carboniferous time. Then in the late Early and Middle Carboniferous the earlier-mentioned sinistral megashear occurred.

Figure 4 displays the paleolatitude patterns as well as the declinational evidence for possible in-situ rotations. The paleolatitudes of Laurentia and Armorica are compared as follows. First, the Atlantic Ocean is closed according to the fit by Bullard et al. (1965). North American cratonic poles have been averaged and the mean paleopoles are used to predict a paleolatitude and a declination for all European sampling sites, taking into account the ages of the rocks at these sites. The differences $(\Delta \phi)$ between observed and predicted paleolatitudes have been used to calculate the averages and standard deviations of Fig. 4; similarly, differences $(\Delta D)$ between predicted and observed declinations are plotted as arrows, all as a function of Paleozoic time. One observes small declination deviations for post-Caledonian time and often large differences for Silurian and earlier time, indicating that local rotations of sampled areas may indeed have been caused by the later deformations in the mobile belts.

The paleolatitude differences are remarkably similar from Ordovician through Early Carboniferous time. If we assume Armorica to be roughly contiguous with the North American craton during the entire middle Paleozoic, allowing for some in-situ block rotations, the constant average value of $15^{\circ}$ for the paleolatitude differences indicates a paleoposition of southern Great Britain to the east of New York State or Vermont, roughly opposite the Catskill delta. The sparse paleomagnetic data for Hercynian Europe, principally from East Germany and Czechoslovakia (Fig. 3), suggest continuity with Great Britain. If, on the other hand, one wishes to have relalive drift between Great Britain and North America during the Late Ordovician and/or Silurian, the paleomagnetic analysis constrains the convergence to one with purely east-west motions.

The conclusion to be drawn from this paleolatitude pattern is that Armorica and 


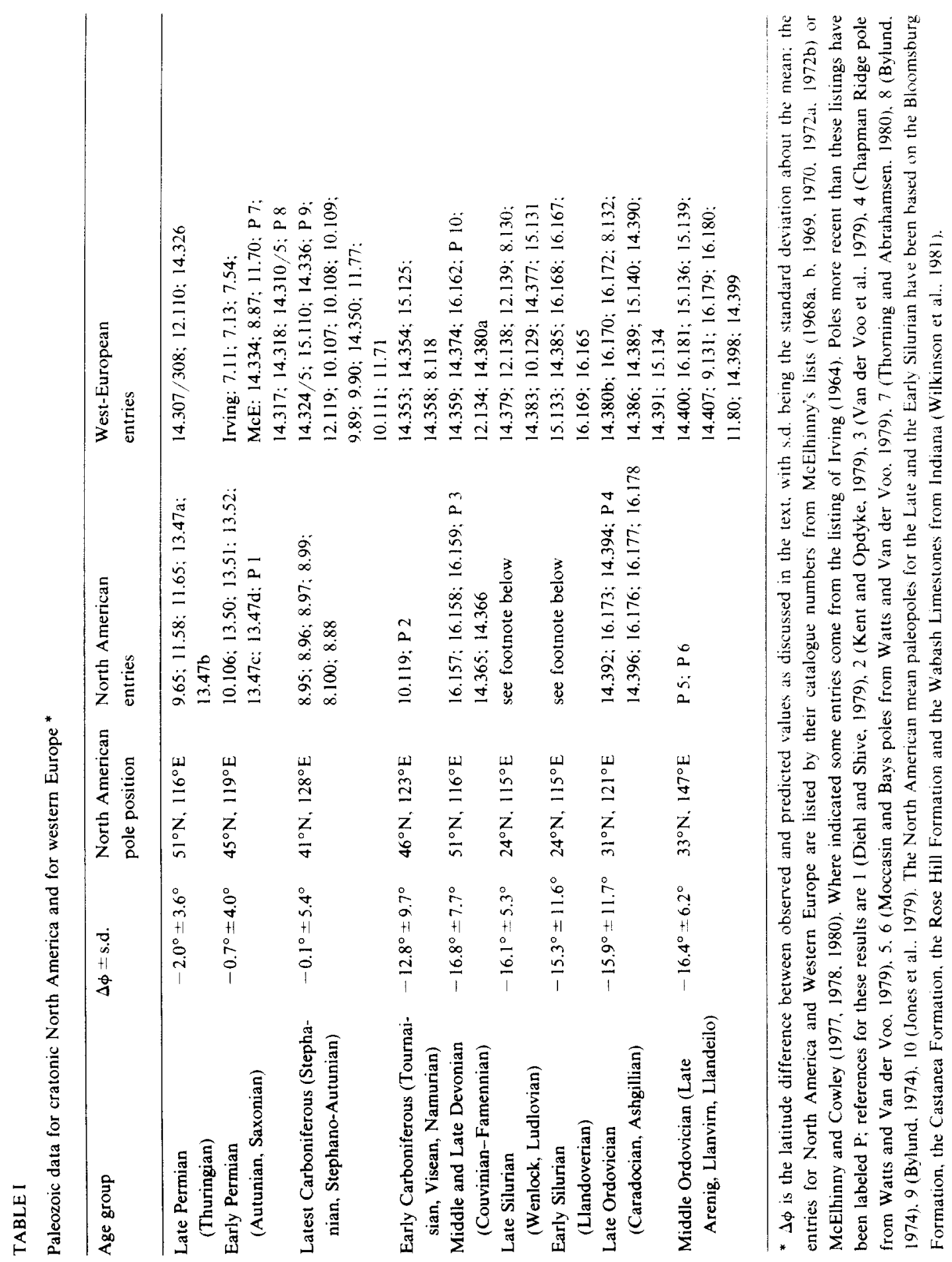




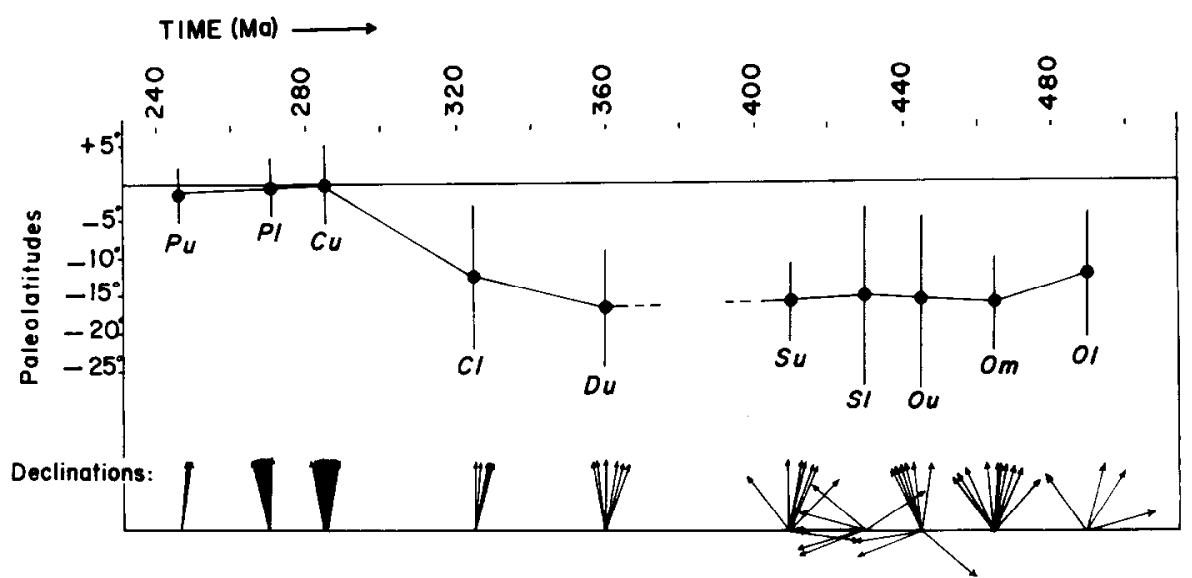

Fig. 4. Paleolatitude and declination differences between Laurentian paleomagnetic data and those for western Europe (mostly from Great Britain south of the Great Glen Fault), plotted as a function of Paleozoic time, and with respect to the fit by Bullard et al. (1965) as explained in the text. The individual paleomagnetic entries are listed in Table I. $P=$ Permian, $C=$ Carboniferous, $D=$ Devonian, $S=$ Silurian, $O=$ Ordovician, and $u=$ upper, $m=$ middle, $l=$ lower.

Laurentia were in similar paleolatitudes from the Late Ordovician onwards, but that the well-known paleomagnetic indeterminancy of paleolongitudes allows, of course, relative paleo-east-west movements. This conclusion forms a constraint on the assembly of the ORC, but does not allow a definite choice between the two models of the previous section. There is, however, an additional argument based on the Middle Ordovician data, which show that by that time Armorica was in all likelihood not very far removed from Laurentia.

This argument can be explained by examination of Fig. 5, which shows hypothetical paleolatitude patterns for Laurentia (with Great Britain in its inferred middle and late Paleozoic positions). Figure 5A shows a pattern of paleolatitudes which are parallel to the Appalachian margin of Laurentia. Such a pattern is seen in North America for Middle Ordovician and earlier time, as suggested by its cratonic paleopoles of Table I. For Late Ordovician, Silurian and later time, on the other hand, the situation of Fig. 5B prevails. It must be obvious that an observed paleolatitude difference of some $15^{\circ}$ implies a real separation between Laurentia and Armorica (i.e., Great Britain) in the case of Fig. 5A, whereas in the situation of Fig. 5B a similar paleolatitude difference does not have to be interpreted as a real separation. Returning now to the diagram of Fig. 4, one can observe that the paleolatitude pattern for Middle and Early Ordovician time implies that Armorica was not directly adjacent to Laurentia, but instead about $15^{\circ}$ removed, whereas in Late Ordovician time it could have been in the southerly position shown in black in Fig. 5B. If true, this reasoning would lead to support of the model involving a Taconic collision between Laurentia and Armorica. 


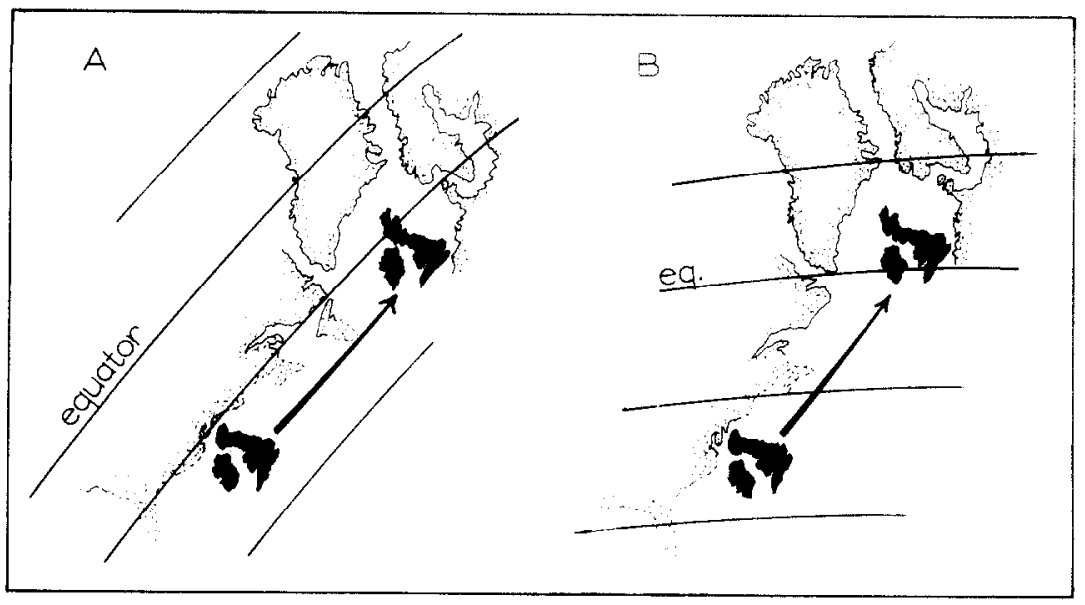

Fig. 5. Hypothetical paleolatitude patterns, showing the possibilities of detecting sinistral megashears of Great Britain with respect to Laurentia or the lack thereof. A. Situation approximately valid for Middle Ordovician and earlier time: no megashear can be detected, but a convergence between Laurentia and Great Britain could be seen, if reliable paleomagnetic data are available. B. Situation approximately valid for Late Ordovician and later Paleozoic time: a megashear can clearly be seen with reliable paleomagnetic data, but paleo-east-west motions are undetectable paleomagnetically.

I would be the first to admit that this argument is circumstantial and rather weak, as other scenarios could be found which explain the data equally well. I want to stress, moreover, that this discussion can not be definitive at this time; instead, it is intended to provide constraints on the basis of the available data, as well as to stimulate future research.

It is only fair, therefore, to also list briefly the aspects of this analysis that could be proven wrong. Foremost, there is the possibility that the Ordovician paleomagnetic field was more complex, as implied by Morris et al. (1979); evidence for this could be found in some of the poles which hitherto have been regarded as anomalous (e.g., Thomas and Briden, 1976). Secondly, it is possible that in the Ordovician and perhaps Silurian, Great Britain and the rest of Armorica were not part of the same plate. After all, the Armorica proposal (Van der Voo, 1979; Hagstrum et al., 1980) is based on late Precambrian-Cambrian paleomagnetism and geological information and on the Devonian paleopoles used in Fig. 1. This leaves an uncertain gap for the Ordovician and Silurian. Finally, the role of Baltica and its relative positions in pre-Devonian time are relatively uncertain because of a paucity of reliable paleopoles. It is clear from the above that for these periods further paleomagnetic work would be extremely valuable. 


\section{DISCUSSION AND CONCLUSIONS}

In the previous sections I have developed two models for the assembly of the ORC, and discussed the constraints on these models provided by the paleomagnetic data. My personal preference is for a model in which Armorica and Laurentia collide in the Late Ordovician, producing the Taconic orogeny. They are then jointed by Baltica in the Late Silurian, producing the Caledonian orogenic belts. Nevertheless, other scenarios, such as Kent's (1980) remain a possibility.

A firm conclusion of this paper is that the available paleomagnetic data from Great Britain show that it was in a constant paleolatitude position with respect to Laurentia, from Late Ordovician to Early Carboniferous time. During the middle Carboniferous, however, a shift occurs during which the European areas of Baltica and Armorica move northward over about $1800 \mathrm{~km}$ with respect to Laurentia. It seems logical to relate this megashear, discussed in more detail by Van der Voo and Scotese (1981), to the impact of Gondwana on the ORC. Lefort and Van der Voo (1981) have argued that this Gondwana-ORC collision was prolonged and not unlike the India-Asia collision models of Molnar and Tapponnier (1977). Paleomagnetic information suggests that by Visean time the collision was imminent, if not already initiated, and that by latest Carboniferous (Stephanian) time the final assembly of the continents involved was accomplished. It can be seen in Fig. 4 that this is precisely the time in which Europe moved northward with respect to Laurentia, ending up in the Bullard et al. (1965) configuration. As Gondwana approached the ORC during the Devonian (see for instance Fig. 1), the intervening ocean must have disappeared through subduction. An accelerated period of mid-Devonian subduction could perhaps explain the Acadian orogeny in the Acadia displaced terrane (Kent and Opdyke, 1978) shown in Fig. 1 to the south of Laurentia, as well as in the southern Hercynian zones of France (e.g., Peucat et al., 1978) which may have been facing this ocean.

\section{ACKNOWLEDGMENTS}

This research was suported by the Division of Earth Sciences, National Science Foundation, grants EAR 76-14996 and 81-03031.

\section{REFERENCES}

Bachtadse, V., Heller, F. and Kröner, A., 1981. Preliminary results of paleomagnetic investigations in the Hercynian realm of middle Europe (abstr.). Int. Assoc. Geomagn. Aeron. Bull., 45: 192.

Bradshaw, J.D., Renouf, J.T. and Taylor, R.T., 1967. The development of Brioverian structures and Brioverian/Paleozoic relationships in west Finistere (France). Geol. Rundsch., 56: 567-596.

Bullard, E.C., Everett, J. and Smith, A.G., 1965. A symposium on continental drift. Philos. Trans. R. Soc. London, Ser. A, 258: 41-51.

Bylund, G., 1974. Paleomagnetism of dykes along the southern margin of the Baltic Shield. Geol. Fören. Stockholm Förh., 96: 231-235. 
Chaloupsky, J, 1978. The Precambrian tectogenesis in the Bohemian Massif. (jeol. Rundsch., 67: 72 -90.

Diehl, J.F, and Shive. P.N., 1979. Paleomagnetic studies of the Early Permian Ingelside Formation of northern Colorado. Geophys. J.R. Astron. Soc., 56: 271-282.

Flügel, H.W., 1975. Einige probleme des Variszikums von Neo-Europa. Geol. Rundsch., 64: 1-62.

Förster, H. and Leonhardt, J., 1972. Dic Otztaler Massc-cin präkambrisches Element in den Ostalpen? Geol. Rundsch., 61: 69-87.

Hagstrum, J.T., Van der Voo, R., Auvray. B. and Bonhommet, N., 1980. Eocambrian-Cambrian paleomagnetism of the Armorican Massif. France. Geophys. J. R. Astron. Soc.. 61. 489.517.

Heinisch, H. and Schmidt, K.. 1976. Zur kaledonischen Orogenese in den Ostalpen. Geol. Rundsch., 65: $459-482$.

Irving, E., 1964. Paleomagnetism and Its Application to Geological and Geophysical Problems. Wiley, New York, 399 pp.

Johnson, G.A.L., 1973. Closing of the Carboniferous sea in western Europe. In: D.H. Tarling and S.K. Runcorn (Editors), Implications of Continental Drift to the Earth Sciences. Academic Press, London. pp. $845-850$.

Johnson, G.A.L.. 1974. Crustal margins and plate tectonics during the Carboniferous. C. R. 7 th Int. Congr. Carboniferous Stratigraphy and Geology, 3: 261-265.

Jones. M., Van der Voo, R. and Bonhommet, N., 1979. Late Devonian to Farly Carboniferous paleomagnetic poles from the Armorican Massif, France. Geophys. J. R. Astron. Soc., 58: 287-308.

Kent, D.V., 1980. Formation of Euramerica in the Paleozoic (abstract). EOS. Trans. Am. Geophys. Union, $61: 220-221$.

Kent, D.V. and Opdyke, N.D., 1978. Paleomagnetism of the Devonian Catskill red beds: evidence for motion of coastal New England-Canadian Maritime region relative to cratonic North America. J. Geophys. Res., 83: 4441-4450.

Kent, D.V. and Opdyke, N.D., 1979. The Early Carboniferous paleomagnetic field for North America and its bearing on the tectonics of the northern Appalachians. Earth Planet. Sci. Lett.. 44: 365-372.

Lefort, J.-P., 1977. Possible "Caledonian" subduction under the Domnonean domain, North Armorican area. Geology, 5: 523-526.

Lefort, J.-P. and Van der Voo, R.. 1981. A kinematic model for the collision and complete suturing between Gondwanaland and Laurasia in the Carboniferous. J. Geol.. 89: 537-550.

MeElhinny, M.W., 1968a. Paleomagnetic directions and pole positions-...VIII. Geophys. J. R. Astron. Soc., 15: $409-430$.

McElhinny, M.W., 1968b. Paleomagnetic directions and pole positions-IX. Geophys. J.R. Astron. Soc., 16: $207-224$.

McElhinny, M.W., 1969. Paleomagnetic directions and pole positions--X. Geophys. J. R. Astron. Soc.. 19: $305-327$.

McLlhinny, M.W., 1970. Palcomagnetic dircetions and pole positions--. XI. Geophys. J. R. Astron. Soc.. 20: $417-429$.

McElhinny, M.W., 1972a. Paleomagnetic directions and pole positions-XII. Geophys. J. R. Astron. Soc.. 27: $237-257$.

McElhinny, M.W., 1972b. Paleomagnetic directions and pole positions-XIII. Geophys. J. R. Astron. Soc., 30: 281-293.

McElhinny, M.W. and Cowley, J.A., 1977. Paleomagnetic directions and pole positions-XIV. Polc numbers 14/1 to 14/574. Geophys. J.R. Astron. Soc., 49: 313-356.

McElhinny, M.W. and Cowley, J.A., 1978. Paleomagnetic directions and pole positions-XV. Pole numbers 15/1 to 15/232. Geophys. J. R. Astron. Soc., 52: 259-276.

McElhinny, M.W. and Cowley, J.A., 1980. Paleomagnetic directions and pole positions-XVI. Pole numbers 16/1 to 16/296. Geophys. J. R. Astron. Soc., 61: 549-571.

Molnar. P. and Tapponnier, P., 1977. Relation of the teclonics of eastern China to the India-Eurasia collision: application of slip-line field theory to large-scale continental tectonics. Geology, 5: 212-216. 
Morris, W.A., 1976. Transcurrent motion determined paleomagnetically in the northern Appalachians and Caledonides and the Acadian orogeny. Can. J. Earth Sci., 13: 1236-1243.

Morris, W.A., Schmidt, P.W. and Roy, J.L., 1979. A graphical approach to polar paths: paleomagnetic cycles and global tectonics. Phys. Earth Planet. Inter., 19: 85-99.

Perroud, H. and Bonhommet, N., 1981. Paleomagnetism of the Ibero-Armorican arc and the Hercynian orogeny in Western Europe. Nature, 292: 445-448.

Peucat, J.J., Le Métour, J. and Audren, C., 1978. Argument géochronologique en faveur de l'existence d'une double ceinture métamorphique d'âge siluro-dévonien en Bretagne méridionale. Bull. Soc. Gèol. Fr., 7: 163-167.

Piper, J.D.A., 1979. Aspects of Caledonian paleomagnetism and their tectonic implications. Earth Planet. Sci. Lett., 44: 176-192.

Priem, H.N.A., Boelrijk, N.A.I.M., Verschure, R.H., Hebeda, E.H. and Floor, P., 1966. Isotopic evidence for Upper Cambrian or Lower Ordovician granite emplacement in the Vigo area, northwestern Spain. Geol. Mijnbouw, 45: 36-40.

Robertson, W.A., Roy, J.L. and Park, J.K., 1968. Magnetization of the Perry Formation of New Brunswick, and the rotation of Newfoundland. Can. J. Earth Sci., 5: 1175-1181.

Schönenberg, R., 1967. Über das Altpaläozoikum der südlichen Ostalpen (Karawanken-Klagenfurter Becken-Saualpenkristallin). Geol. Rundsch., 56: 473-480.

Schwan, W., 1962. Zur Entstehung der Plauener Bögen im Vogtländer Schiefergebirge. Geol. Rundsch., 52: $782-804$.

Scotese, C.R., Bambach, R.K., Barton, C., Van der Voo, R. and Ziegler, A.M., 1979. Paleozoic base maps. J. Geol., 87: 217-277.

Stille, H., 1924. Grundfragen der vergleichenden Tektonik. Bornträger, Berlin, 443 pp.

Thomas, C. and Briden, J.C., 1976. Anomalous geomagnetic field during the Late Ordovician. Nature, 259: $380-382$.

Thorning, L. and Abrahamsen, N., 1980. Paleomagnetism of multiple intrusion dykes in Bohuslän, southwest Sweden. Geophys. J. R. Astron. Soc., 60: 163-186.

Van der Voo, R., 1979. Paleozoic assembly of Pangea: a new plate tectonic model for the Taconic, Caledonian, and Hercynian orogenies (abstr.). EOS, Trans. Am. Geophys. Union, 60: 241.

Van der Voo, R., 1982. Pre-Mesozoic paleomagnetism and plate tectonics. Annu. Rev. Earth Planet. Sci., 10: 191220.

Van der Voo, R. and Scotese, C.R., 1981. Paleomagnetic evidence for a large ( $\sim 2000 \mathrm{~km})$ sinistral offset along the Great Glen Fault during the Carboniferous. Geology, 9: 583-589.

Van der Voo, R., French, A.N. and French, R.B., 1979. A paleomagnetic pole position from the folded Upper Devonian Catskill red beds, and its tectonic implications. Geology, 7: 345-348.

Vardabasso, S., 1963. Die ausseralpine Taphrogenese im Kaledonisch-Variszisch konsolidierten Sardischen Vorlande. Geol. Rundsch., 53: 613-630.

Watts, D.R. and Van der Voo, R., 1979. Paleomagnetic results from the Ordovician Moccasin, Bays, and Chapman Ridge formations of the Valley and Ridge province, eastern Tennessee. J. Geophys. Res., 84: 645-655.

Wilkinson, B.H., Van der Voo, R. and McCaben, C., 1981. Paleomagnetism of Silurian reef limestones in Ohio and Indiana (abstr.). EOS, Trans. Am. Geophys. Union, 62: 271-272.

Ziegler, P., 1978. Northwestern Europe: tectonics and basement development. Geol. Mijnbouw, 57: 589-626.

Zwart, H.J. and Dornsiepen, U.F., 1978. The tectonic framework of Central and Western Europe. Geol. Mijnbouw, 57: 627-654. 